\title{
Open-air Conservation of Ruins and the Concept of "Non-Dislocation"
}

\author{
Aldo R. D. Accardi ${ }^{1}$ \\ ${ }^{1}$ Department of Architecture, University of Palermo, Palermo, Italy \\ Correspondence: Aldo R. D. Accardi, Department of Architecture, University of Palermo, Viale delle Scienze, \\ Palermo 90128, Sicily, Italy. Tel: 39-091-361-952. E-mail: aldo.accardi@libero.it
}

Received: March 9, 2012 Accepted: April 11, 2012 Online Published: July 1, 2012

doi:10.5539/ach.v4n2p109 URL: http://dx.doi.org/10.5539/ach.v4n2p109

\begin{abstract}
Most of the on-going debate is about "how" to protect archaeological ruins, whilst at the same time allowing the general public to enjoy them. Today it is clear how important it is, from the actual planning stages of excavations, to interact with experts from other disciplines, who are working on their own findings and offering them up for collective enjoyment. Whatever might be feasible for an indoor museum is not always feasible with an architectonic ruin, as regards both presenting objects with explicative apparatus that determines their significance, and exploring them in a new way when interpretations change or new ideologies are introduced. First of all, conserving excavations is the not the same as conserving a transportable object. In the past many countries in Europe preferred to "present" Roman remains simply as "gardens of ruins", often endeavouring to stand them in sharp contrast with a more recurrent evocation of the original contexts of local life. Recently, with regard to the Roman tradition, there has been a noticeable inversion of trend in musealization operations, according to which the mere "contemplation of ruins" should be replaced by emotional contact with history. The main consequence of these new tendencies is the replacement of an informatics-based and didactic approach to musealization, in favour of a more authentically interpretative approach. Back-up resulting from experimentation in the fields of restoration and conservation becomes indispensible in implementing these new strategies for the musealization of archaeology. Continuous research and the progressive advance of conservation techniques have meant that the need to transfer archaeological remains has been avoided and an improved in situ "presentation" of these remains, both movable and immovable, can now be guaranteed.
\end{abstract}

Keywords: heritage conservation, archaeological sites, open-air musealization

\section{Introduction}

When the idea of conservation is also understood as conservation for the general public/tourism there is a risk of coming into conflict with scientific research, and above all with the process of safeguarding remains "abandoned" in the field by research itself. Most of contemporary debate does in fact centre around the criteria for safeguarding archaeological remains in such a way that this can be accomplished without having to affect public enjoyment of the object in question. Today, archaeologists concerned about the future of our past have realised how indispensable it is, from the earliest planning stages of an excavation campaign, to interact with professionals from other disciplines, be they curators, restorers, historians, museologists or museographers, all dealing with their findings in order to deliver them up for collective enjoyment; simply speaking the archaeological heritage is to be considered a public asset and the more the experimentation the greater the possibility that it will not be forsaken or, even worse, destroyed.

It is obviously not possible to treat open-air ruins in the same way as an indoor museographic operation, both with regard to presentation by means of interpretative apparatus defining the significance of the "item" created (Note 1) and to the ways in which it is exhibited; these inevitably change with every fresh interpretation or with the introduction of new ideologies, which "have nothing to do with the objects, but which, however, end up colliding with the general conception of what they represent or how they should be represented". First of all, conserving an excavated site is not the same as conserving a transportable object; any intervention carried out on ruins is always irreversible; no restoration, however big or small, can ever be considered fully reversible (Note 2). 
In fact there is a recent British Museum paper titled: Reversibility - Does it exist? (Oddy \& Carrol, 1999). The concept of irreversibility responds to Ruskinian thinking, which is wholeheartedly embraced by the British archaeological community, with one of the consequences being the almost total refusal of the dominant cultural trend in Germany, i.e. the marked passion for in situ philological reconstructions. Although British archaeologists have taken their distance from these practices, Great Britain does offer several examples of reconstructive interventions (Note 3).

The systemic complexity with regard to the co-presence of a variety of actions (safeguard, presentation and musealization) carried out in an open-air site, poses more than a few questions, most of which can only be answered at the end of the actual conservation process as seen from a holistic perspective (Note 4). To plan a conservation intervention from this holistic perspective means that, on the part of the general public, enjoyment of an archaeological ruin is also inevitably extended to the surrounding context, with its material (physical) and spiritual (non-material) values. Were all these values to be thrown together into the melting-pot of sustainable exploitation, they might jeopardize the actual opportunity of "giving back" to the general public these archaeological remains. In fact, when it is not possible to safeguard all the values, the so-called "non-codifiable" choices, which belong more readily to the sphere of ethics, come into play. Whoever finds himself operating in sensitive areas, from the conservational point of view, will always be forced to make an ethical (and not scientific) assessment with regard to "what" can be sacrificed and "what else" can be turned to account. For example, in order not to interfere with the skyline of an (urban or rural) landscape, how can one objectively decide whether it may be opportune to "re-inter" the pre-existing item, and thus surrender the opportunity of exploiting it through the juxtaposition of a protective and, wherever possible, musealized structure? These are planning problems that cannot easily be solved and which still today foment on-going, open international discussion. It needs to be acknowledged, however, that in Europe there are countless examples in which the safeguarding of all relevant values can be said to be entirely successful (Note 5).

\section{Some French Examples of Open-Air Conservation of Ruins}

Especially in the recent past, and in the wake of the above-mentioned attitudes, many countries in the rest of Europe have been worried about interfering with the nature of a place or trivialising a site with roofing-structures or by closing off ruins. They have in fact often preferred "to present" the vestiges simply as "gardens of ruins", particularly Roman ruins, taking pains to show them off and contrast them sharply with a more recurrent re-evocation of the original contexts of local life; the presence of Roman architecture in the background might actually serve to exalt the "native" populations (Note 6).

An approach very similar to the one just mentioned was applied in the archaeological site at Séviac, near Montréal du Gers (Dip. Gers), in which the utilisation of "vernacular" architecture sets a grand Gallic-Roman villa against a rural backdrop. In this case "vernacular" (Note 7) is a synonym for indigenous, domestic architecture and underlines an indifference to influences from other cultures, and restores greater consideration to the original cultural heritage, seen as an instrument for understanding a community, i.e. the real genius loci. In fact, with the creation of vernacular-style roofing, the present intervention to protect the ruins seems to recapture the ancient Celto-Gallic spirit better than might have been the case with the more evident Roman cultural matrix and construction-techniques. This great archaeological complex, dating back to the 2 nd cent. A.D., today stands out because of the ruins of the private baths and the afore-mentioned villa, built around two garden-courtyards delimited by a marble-columned peristyle; and then above all, from the residential part, there is the unique series of late-Empire polychrome mosaics, among which one can admire the famous "mosaïque aux arbres".

The most important remains at Séviac have been preserved in situ, including the polychrome mosaics (Note 8), which have thus been kept in a rural and traditional context that bestows upon the archaeological whole a rural character that is not entirely satisfying. Since 1979 several protective structures have been built in the areas at risk of degradation (including those still marked by the presence of in loco mosaics); these pavilions of rough-hewn wood and tile-roofs recapture the traditional partial roofing much-used in the world of Anglo-Saxon conservation (Note 9), but without the slavish intention to reconfigure the original forms.

In the same way, only a few years later (1989), another Gallo-Roman structure (baths to be more precise) was covered with a protective wooden structure, again respecting the traditional "local style". This took place in the municipality of present-day Chassenon, which is to say, among the largest and best-preserved monumental structures in the Roman Empire, that of Cassinomagus. The archaeological complex, an ancient Gallo-Roman rural sanctuary built between the 1st and 4th century A.D., emerged largely because of its extraordinary size and the ingenuity of the building systems employed, but mainly because of the exceptional state of conservation (Note 10), which enabled one to easily recognise the original functions of the spaces into which it was divided. 
In the roofing system adopted to protect the ruins, it was possible to discern the influence of vernacular architecture of a Celtic matrix (though filtered through the obvious Roman "presence"), expressed by the massive stone walls and the virtuosity of the building techniques. Apart from the remarkably high outer walls, part of the heating and water distribution systems have survived, along with paved swimming pools, a great number of statues and artefacts. The previous guided tour wound its way through the ruins, following the original series of links, occasionally interrupted by the unstable condition of the paving and the considerable difference in level between the walking surfaces. The continuity of the itinerary was guaranteed by a raised system of wooden walkways.
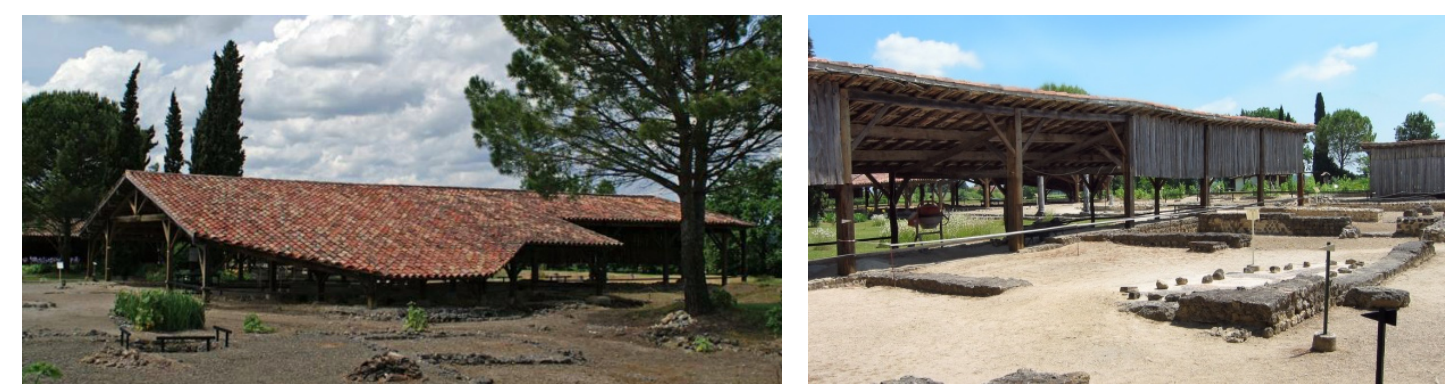

Figures $1 \& 2$. The Gallic-Roman villa at Séviac

One can discern the utilisation of a vernacular idiom in the roofing over the ruins
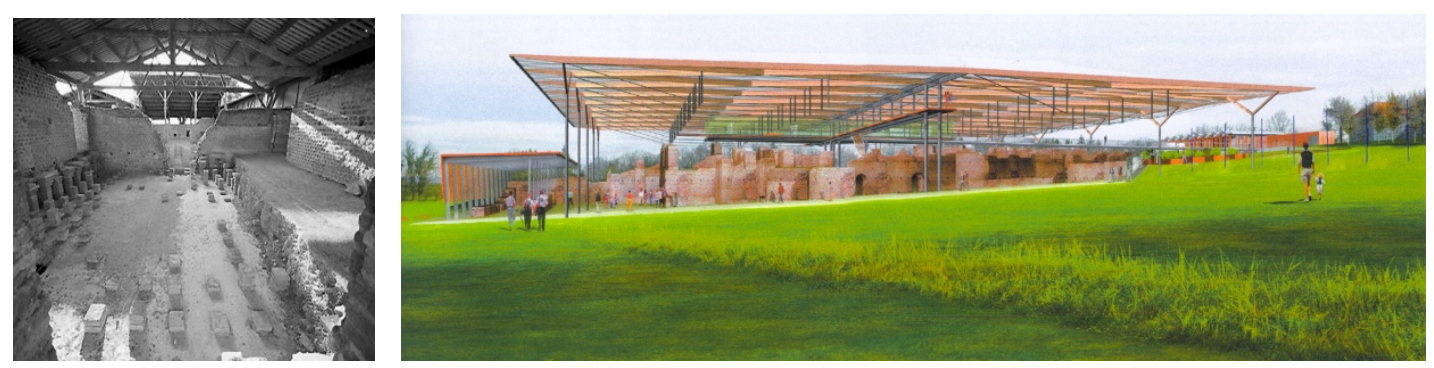

Figures 3 \& 4. Cassinomagus Baths

On the left, an internal view of the ancient roofing system; on the right, a view of the forthcoming re-structuring, in accordance with the Atélier Kérosène project (drawings by Antoine Renaud - Atélier Kérosène).

The new show-casing project (Note 11) has emerged from the intention to offer greater conservational guarantees and a greater possibility for enjoyment, and envisages a radical transformation of the present-day site in favour of a hyper-technological and multi-functional protective structure; this is a definite improvement over the ancient roofing, which was rather too characteristic of the peculiar organic nature of the vernacular architecture. In fact, the most ambitious part of the project actually consists in covering the ruins of the baths with a large horizontal plait. In a position corresponding to the symmetric axis of the baths, a metal structural girder will constitute the "spinal column" of the roofing, resting on two series of supports (also of metal) positioned at the sides West and East of the ruins; the area of the baths will thus be left free, avoiding the interposition of further supports among the archaeological ruins (Note 12). A suspended gallery, called galerie d'interprétation, and held up by the central girder, permits the visitor, starting from the reception building, to look out progressively on to the ruins and to take in the whole lay-out. A network of secondary girders will be fixed to the main framework, so as to form a support for the waterproof protective sheet, which, in its turn, will allow natural light through, utilising serigraphy to dose the light in function of the nature of the underlying areas. The new roofing, in contrast to the previous structure, will stand out in the landscape, along with the other "additional" structures envisaged for receiving the general public, the temporary exhibitions and the special interpretative tools. As regards the viewing point for the ruins, the impending museographic "mechanism" promises a complete communicational back-up, boasting the most up-to-date presentation techniques for archaeology; mention might here be made of multi-media projections, holograms, lighting-effects, sound re-evocation etc. All in all, whatever is lost through the poor re-configurative approach to protection, will be compensated by the communicational power of the internal musealization. 
In fact, it is with regard to operations involving the musealization of the "Roman spirit" that a trend has recently come into prominence, according to which "contemplation of ruins" sic et simpliciter should be replaced by emotional contact with history. The visitor establishes this contact both through experiencing the open-air display, and through direct involvement in activities of archaeological research. The real innovation in this approach is actually represented by architectonic research, which is filtered through the most innovative museographic requirements and plays a determining role, since it finds accord between the demands of conservation, presentation, respect for what lies underground and the present-day orientation towards beautification (Note 13); as the archaeologist Kevin Walsh points out in this regard, if taken to extremes, this approach might not take into account all those aspects from the past that do not actually contribute to the construction of something generally pleasing and harmonious, and might thus privilege the more spectacular aspects of the territory, seen almost exclusively through the eyes of the beholder. The Roman ruins become "traces" of something else, elements calling to mind a natural landscape in which ancient civilisations settled and for this reason the sense of the creation of these archaeological gardens with Roman ruins is, in most cases, characterised by the historical mise en valeur of the natural elements rather than the individual ruins themselves (Note 14).

In 1994 the Conseil général de l'Eure decided to embark on a project to show-case the Gallic-Roman baths at Gisacum (Note 15), with the aim of transforming the ruins into an "archaeological garden". It was only in 2001 that the local administration planned a real musealization of the site, and to this end an architecture competition was announced, laying down extremely detailed directions for the project, especially with regard to the restoration of the ruins and the creation of a structure for educational purposes sited in an attractive scenic setting (Note 16). The imperative to protect the archaeological traces restricted archaeological exploration in situ and triggered off a particular form of "wholesale protection", contrasted with bold, and at the same time communicative, presentational ploys. Within a framework of show-casing the Baths, the project emphasises above all the educational dimension, with the objective of putting on display a significant work of ancient architecture and rendering it intelligible to the general public. The possibility of total reconstruction was disregarded because it was not really desirable and the costs were too daunting; a proposal was then put forward to "re-evoke" the architecture by using particular devices, which, in the absence of an overall roofing structure, and apart from a specific interpretative purpose, would take on the function of protecting the walls above ground. In order to prevent the elements and the presence of Man from rapidly causing damage, the whole site was a covered with a protective geotextile layer, on which soil for plants was placed, in order to preserve the porosity and natural hygrometry of the terrain.

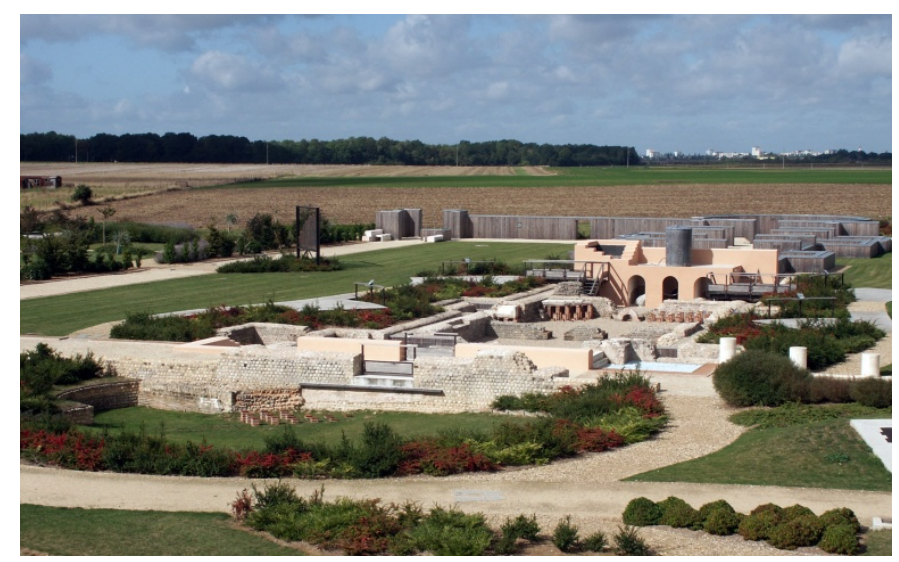

Figure 5. Gallic-Roman Baths at Gisacum

The open-air presentation system of the ruins (by F. Grimaud, Mission Archéologique Départementale de L'Eure).

Here, above the hygrometric barrier, the traces extruded that suggest the outline of walls present underground (the result of lined-out museographic practice), help in restitution of the entire ground-plan of the lay-out of the Baths. In order to compensate for the lack of vertical elements and render all parts intelligible, a few archaeological items (such as portions of pools and hypocausts) have been reconstructed using both traditional materials and contemporary techniques and laid out along the guided visitors' path. In line with the idea of maintaining the ruins in their original state, sections of wall emerging above ground were provided with special "coating layers" made from traditional lime mortar, treated with a water-repellent solution.

The afore-mentioned lined-out archaeological presentation therefore enables one to render visible parts of walls 
that are still interred; these have been virtually "extruded" by a wooden box-structure, surmounted and sealed off with a zinc protective covering - a decidedly bold, aesthetic choice, costing very little and, most importantly, being reversible. These wooden faces are arranged to follow the line of the underlying walls, or overlaid on portions of wall above ground, and escort visitors in their exploration of the various areas of the Baths; these latter structures themselves no longer exist, but can be clearly imagined, represented as they are by the elevation of the perimeter-wall sections, which in some cases reach a height of over two metres. The employment of coloured gravel not only helps distinguish originally roofed areas from those in the open, but also the private from the public, whilst enabling the visitor to single out the various functions of the Baths; the flooring takes on different shades of blue, with devices simulating the Baths at high water, similar those of the Roman baths at Caerleon (Note 17). The case of Gisacum represents one of the possible approaches identified in the French interventionist panorama, documented, moreover, by a wide variety of archaeology show-casing experiences. Almost paradoxically, this variety means that each of these experiences from time to time constitutes an extreme case for intervention but in no way delegitimizes the projects even though there might be considerable dissimilarity between one project and another, with each intervention being geared towards quite different scenarios.

The case of the Parc Archéologique Européen Bliesbruck-Reinheim is rather different, being acknowledged mainly for the bold approach to the ruins, with the utilisation of contemporary structures, in line with criteria quite similar to those employed in the roofing operations at Montcaret, Périgueux and Loupian. In the Roman epoch the area was covered by a dense road network, with numerous inhabited centres, farms and isolated fields (villae). Several of these centres, such as Bliesbruck, were renowned for their handicrafts and as regional markets. The union with nearby Reinheim, which took place around the middle of the $1^{\text {st }}$ cent. A.D., gave life to a thriving centre, which reached its height of development in the first half of the $3^{\text {rd }}$ cent. A.D. (Note 18). Following recent excavations evidence of the existence of the main axis through the ancient urban conglomeration has come to light, and traces of numerous artisans' quarters have been revealed (Note 19). The archaeological park at Bliesbruck-Reinheim has a centre for archaeological research and experimentation, a "diffused" museographic system (with thematic pavilions scattered around the park), a site-museum, which, apart from providing an overview of the park, houses exhibitions (that are in continual evolution in function of fresh discoveries), several life-size reconstructions and reception facilities. Each of these museographic elements lives and breathes within the wider mise en valeur of the whole landscape.

Whilst the scientific aspect is entrusted to the research centre, the museographic and educational aspects are in the hands of numerous separate structures, in particular the Pavillon des Thermes (1993), reflecting the most up-to-date museographic models and educational-exhibitory criteria, which allow the general public to move about easily and independently. It was designed "to exhibit" and, at the same time, "to protect" the remains of the Roman Baths, which were particularly prone to degradation. The building evokes rural architecture and stands out as a visible landmark in the surrounding area; this large structure was built over the original ruins and was covered with extended curved copper centring, resting on wooden and metal supports, through which a viewing itinerary winds its way, based around a "suspended" system of walkways held up by a structured latticework of steel bars set out among the trusses. The walkways above the ruins are positioned at the approximate height of the original floors, offering the visitor an overall vision of the lay-out of the buildings and their functioning. These walkways are a tool of "discovery" and not "restitution"; the visitors understand that they are not walking along the original paths which have been adjusted by about four degrees in relation to the direction of the ancient paths.

The image of the Pavillon des Thermes is characterised by recurring, hi-tech, curved shapes, the building material of which is almost exclusively wood, glass and metal; these are a recurring element in all the other new buildings on the site, from the protective roofing of the ruins to the excavation modules. Although the museum stands out clearly against the skyline, the wooden facing and copper roofing, which has gradually taken on a green hue, help the structure blend into the landscape. Initial attention was concentrated principally on the splendid Baths and their subsequent conservation; as regards the outdoor ruins, a more recurrent practice of conservation was carried out, which first of all entailed the mere levelling of walls, with partial integrations, and highlighting the flooring with gravel of different colours, etc. This technique for recovery and presentation had already been tried out in many archaeological sites in other départements, often quite a long way from each other; one might mention, for example, the Roman baths at the archaeological site of Barzan (Charente-Maritime), but also the classic cleaning operations and attentive maintenance characteristic of many English sites.

Unlike the previously-mentioned case, the Saint-Romain-en-Gal site (Rhône) boasts a museum (Note 20) that integrates architectonic virtuosity, a relationship with the site and intelligibility of the ruins, whilst also aspiring 
to an aura of exceptional grandeur. The ostentatious use of metal and glass, in clear contrast with the stone of the ruins, reflects the desire not to conform with traditional building systems from the Roman epoch and makes a clear statement about the nature of the building, blankly refusing to compete in any way with the intense historical vestiges.

Sited in a bend in the river Rhone, the flood plain of the rive droit of the river (under the local municipal authority of Saint-Romain-en-Gal and Sainte-Colombe) has been the preferred subject of the authors from Vienne since the $17^{\text {th }}$ century, because of its wealth of antiquities and the great number of finds, especially mosaics (Note 21). Around 1968, the unexpected discovery of traces of ancient Vienne ( $1^{\text {st }}$ cent. B.C), one of the richest cities in Gaul, led to the individuation of a large, originally very densely built-up, artisans' and residential quarter (Note 22). What needs to be emphasised here is the similarity between all the open-air protection operations in the case-studies hitherto cited. The outdoor areas of the site in Vienne are also extremely well laid-out; the particular attention devoted to the walls helps them stand out clearly. There is great variety among the open-air ruins, with a wealth of mosaics maintained in situ (and not dislocated for the most part), reconstructed gardens with pergolas and buildings for bathing, all presented in line with an intervention approach that has been appraised several times; this system entails the levelling-out of outer walls (with the overlaying of fresh stone material), partial completion of the structures, recognition of internal/external spaces through the use of coloured gravel and the juxtaposition of newly-created elements as metric parameters of comparison (e.g. columns placed at intervals corresponding to pre-existing remains). Reconstructions of a summer triclinium and lavatories stand out among the ruins. From time to time representations of battles and scenes from Roman life are mises en scène in order to increase knowledge of the city's past and shape the visitor's awareness, as part of a controlled educational process already initiated at the museum. The main upshot of these new approaches consists in overcoming the informative and didactic character of musealization in favour of a more authentically interpretative approach. Expressive systems of a highly narrative (and often rather audacious) character have been set up with regard to this new trend, the fruit of mediation between a romantic sense of "contemplating the ruins" and a modern desire to filter history through new instruments of interpretation.

\section{Conclusion}

It might now seem clear that, in the creation of these new strategies for the safeguard and musealization of archaeology, the support emerging from experimentation in the field of restoration and conservation is indispensible. Research goes on and the continual advances in conservational techniques now mean that a more faithful "presentation" of ruins in situ might be achieved, avoiding both the ravages of time and the elements and, wherever possible, their dislocation.
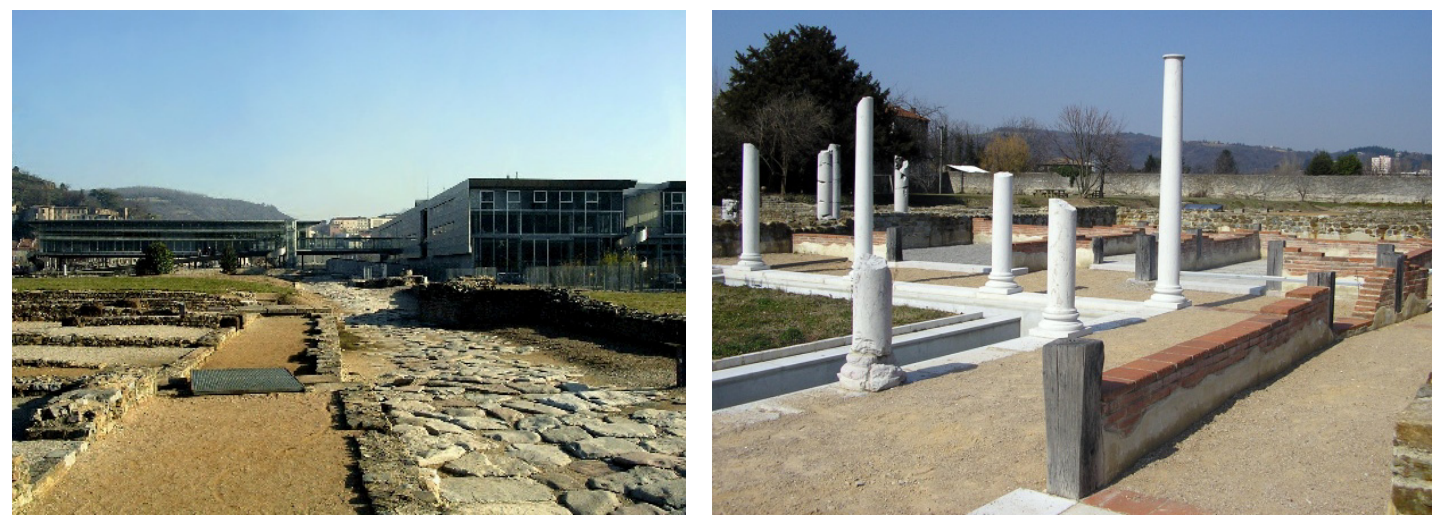

Figures $6 \&$ 7. The Saint-Romain-en-Gal site, Vienne

On the left, a view of the ruins with museum buildings (housing the permanent exhibition) in the background; on the right, the presentation of the ruins in various approaches to open-air exhibition. 

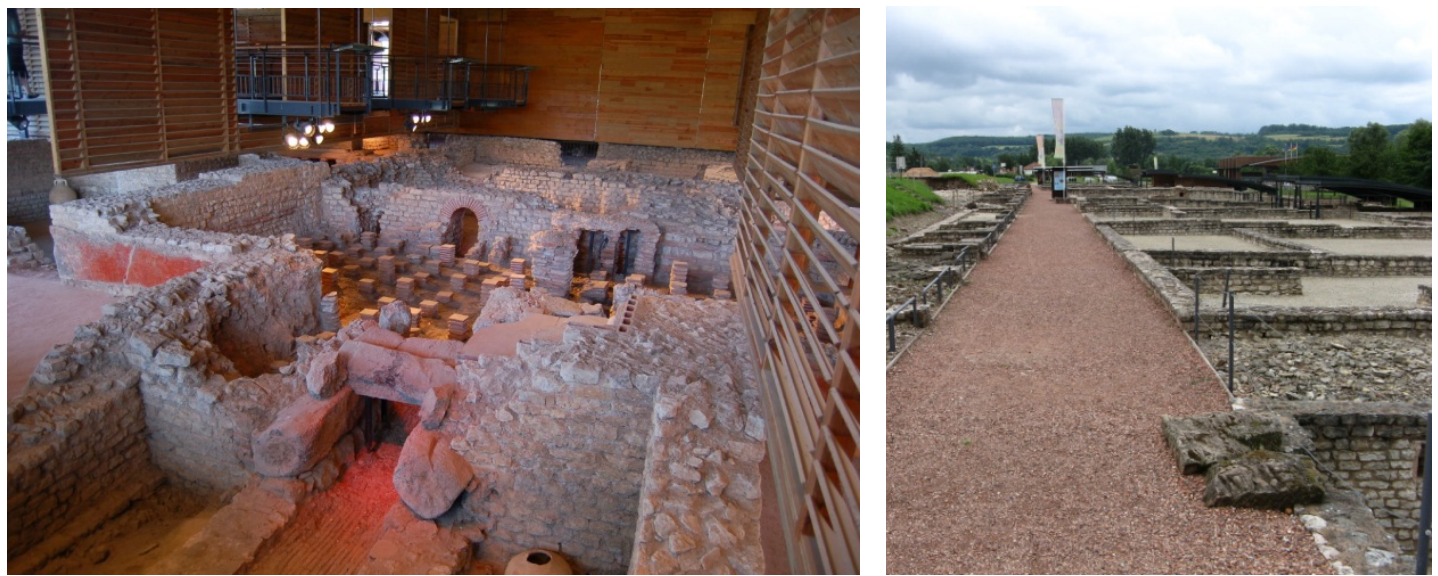

Figures 8 \& 9. Parc Archéologique de Bliesbruck-Reinheim

Left, internal view of the "Pavillion des Thermes" (1993); right, artisans' quarter West; to be noted the levelling-out of the outer walls and the clear demarcation of the areas.
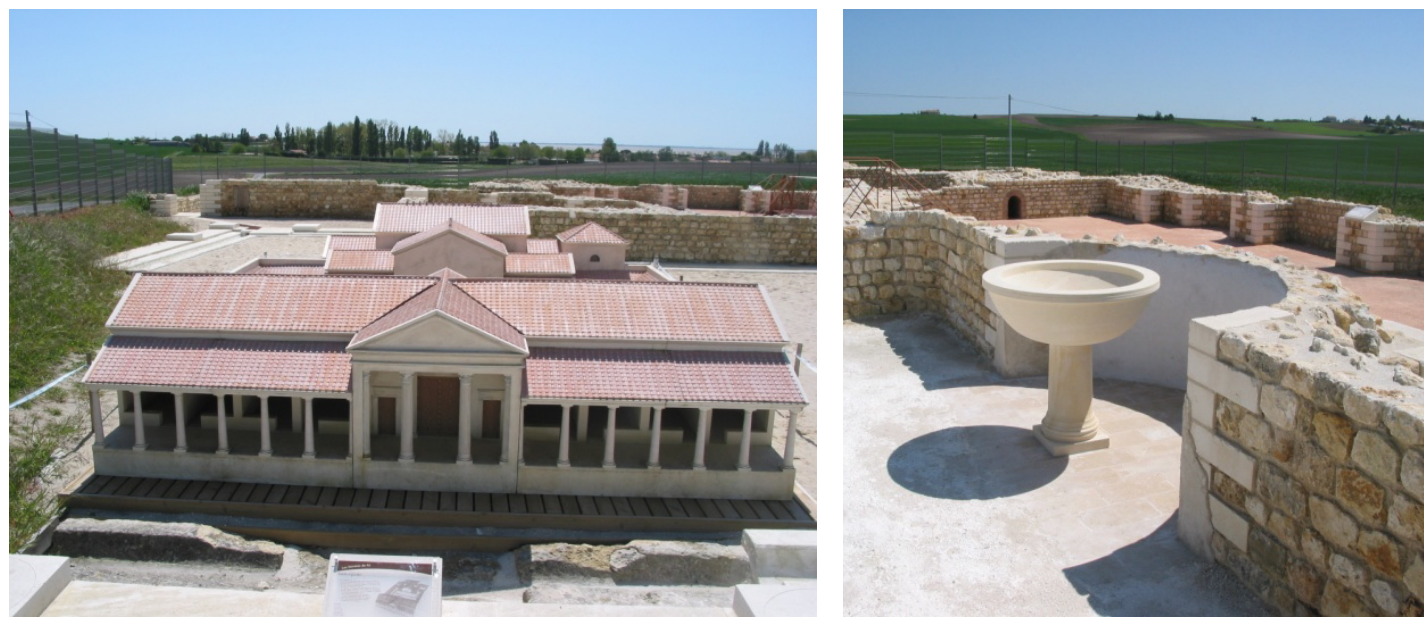

Figures 10 \& 11. The Barzan site, also called du Fâ, Novioregum Eaths

Left, the spectacular reduced-scale model of the Bathing complex, positioned among the ruins, provides a three-dimensional view of the monument and an assessment of its architectonic components in a direct comparison with the ruins; right, in situ exhibition of the finds.

\section{References}

Accardi, A. R. D. (2005). Un caso di living archaeology: Bibracte ed il Museo della civiltà celtica. In T. M. C. Ruggieri, \& S. Rugino (Eds), Luoghi, storie, musei. Percorsi e prospettive dei musei del luogo nell'epoca della globalizzazione (pp. 145-160). Dario Flaccovio Editore, Palermo.

Accardi, A. R. D. (2007). La musealizzazione delle rovine a Gisacum, Francia. In A. Sposito (cur.), Agathón 2007 (pp. 41-44). DPCE, Palermo.

Agnew, N. (1997). Preservation of Archaeological Sites: an Holistic Perspective. The Getty Conservation Institute newsletter. Retrieved from http://www.getty.edu/conservation/publications/newsletters/12_2/feature1.html

Agnew, N., \& Bridgland, J. (eds.) (2006). Of the Past, for the Future: Integrating Archaeology and Conservation (pp. 306-311). proceedings of the Conservation Theme at the $5^{\text {th }}$ World Archaeological Congress (Washington, D.C. 22-26 June 2003). The Getty Conservation Institute, Los Angeles.

Aitchison, C., Macleod, N. E., \& Shaw, S. J. (2000). Leisure and Tourism Landscapes. Social and cultural geographies. Routledge, London and New York.

Brunella, P., \& Petit, J. P. (2003). Entre l'air et le couvert, le Parc Archéologique Européen de Bliesbruck-Reinheim. Les Vestiges archéologiques en milieu extrême: étude et conservation (pp. 164-178). 
Clermont-Ferrand, Paris.

Fowler, P. J. (1995). The Past in the Contemporary Society. Then, Now. London and New York: Routledge.

Goodburn-Brown, D., \& Panter, I. (2004). Reburial in the context of development: Approaches to reburial in the English planning process. Conservation and Management of Archaeological Sites (pp. 275-284). Maney Publishing. http://dx.doi.org/10.1179/135050304793137865

Goudineau, C., \& Guilaine, J. (curs.) (1991). De Lascaux au Grand Louvre. Archéologie et Histoire de la France. Errance, Paris.

Massy, J. L. (dir.) (1997). Les agglomérations secondaires de la Lorraine romaine. Besançon.

Oddy, A., \& Carrol, S. (eds.) (1999). Reversibility - Does it exist?. British Museum Occasional Paper (nR 135). London.

Parent, M. (1975). L'architecture vernaculaire rurale, ses modes de conservation et ses limites a l'adaptation. Les monuments historiques, 21.

Pelletier, A. (1982). Vienne antique, des origines aux invasions alamaniques. Roanne.

Robert, J. P. (1997). Musée archéologique, Saint-Romain-en-Gal et Vienne. L'Architecture d'Aujourd'hui, 309, 32-49.

Ruggieri, T. M. C. (2000). I fantasmi e le cose. La messa in scena della storia nella comunicazione museale. Lybra Immagine, Milano.

Ruggieri, T. M. C. (2007). Musei sulle Rovine. Architetture nel contesto archeologico. Lybra Immagine, Milano. Strike, J. (1994). Architecture in Conservation. Managing Development at Historic Sites. London and New York.

Walsh, K. (1997). The Representation of the Past. Museums and Heritage in the post-modern World. London and New York: Routledge.

Zaoui, M. (1997). Special issue: Musées. Techniques \& Architecture, 431, 33-88.

\section{Notes}

Note 1. A wide-ranging panorama of presentation strategies for objects is illustrated in the article of Neville Agnew and Janet Bridgland (Agnew \& Bridgland, 2006).

Note 2. Much of the literature in this sector argues about the objective impossibility of intervening in reversible fashion in any case. In this sense, in the case of archaeological ruins, one either decides to leave the pre-existing item in the open in the conditions in which it was restored to the light of day, or, as happens in the scientific practices of archaeologists from the Anglo-Saxon world, to proceed with its immediate re-interment. In England re-burial is never considered a makeshift remedy, but on the contrary, an operation of great civil and scientific respect for "future generations"; (Goodburn-Brown \& Panther, 2004).

Note 3. Apart from the better-known intervention on Cardiff Castle, q.v. the Roman gate of Manchester Castle, Roman forts at Segedunum, Arbeia, Lunt and others.

Note 4. 1999 saw the international adoption of the Carta di Burra, renowned for arranging the phases of the conservational process, but worth noting here because of those points in which the cultural value of the monuments is defined as an aesthetic, historical, scientific, social, political and spiritual value; i.e. that the totality of values of a heritage is rendered natural in the actual place itself and is made up of real (or physical) aspects as well as various associated non-material values; hence the definition of holistic perspective (Agnew, 1997).

Note 5. Q.v. in this regard, the great number of cases of architectural operations on ruins as examined by Maria Clara Ruggieri Tricoli (Ruggieri Tricoli, 2007).

Note 6. Many cases of this type have been examined by Maria Clara Ruggieri Tricoli (Ruggieri Tricoli, M. C., 2000); q.v. also Aldo R. D. Accardi, especially the part in which express reference is made to the project of musealization in Alésia at the Archéodrome de Bourgogne (Accardi, 2005).

Note 7. Etymologically the vernacular term (from "verna"), harks back to the opposition between the architecture of the "masters" and that of the "servants". This definition might highlight the condition of whoever is working, which, in the configuration of the pre-industrialised world, leads to identifying vernacular architecture with working-class, rural architecture (Parent, 1975, pp. 4-8). For aspects linked to the close relationship between landscape and vernacular architecture, q.v. the so-called Celtic background, cited by Maria Clara Ruggieri Tricoli (Ruggieri Tricoli, 2007, p. 42). 
Note 8. During the period of winter-closing mosaic paving is covered with a thick layer of sand, which protects it from extremes of temperature.

Note 9. In protective operations carried out in the Gallo-Roman villas, the adoption of a vernacular idiom expresses an attitude (often encountered in other European contexts) according to which the villae are seen as testimony to the rural life, rather than actual monuments. Cf. in this sense, with the case of the Bignor villa in Sussex (Ruggieri Tricoli, 2007, pp. 61-69).

Note 10. The excellent state of conservation permits one to appreciate several ancient walls at varying heights (from 5 to $7 \mathrm{~m}$ ), baths, vaulted subterranean halls, boilers and portions of painted plasterwork. Visiting the building from the outside, the visitor's attention is drawn to the succession of great openings in the walls that are still recognisable in their original settings, which convey the idea of the degree of lighting that once existed in closed habitats.

Note 11. The project, which has now progressed to the execution phase, was awarded in 2005 to the architect Antoine Renaud of the Atélier Kérosène, the same group of professionals who designed the system of musealization adopted in Parc Archéologique Européen Bliesbruck-Reinheim, Infra.

Note 12. The East and West sides of the roofing are in their turn held up by further metal supports, halved at the top, and positioned not far from the perimeter walls of the Baths. The tension to which the large structure is subjected is relaxed by a system of taut metal cables and (mixed wooden and metal) punches, which work by compression (in line with the principle of the well-known Polonceau truss).

Note 13. In many foreign countries, more so than in Italy, the outcome of these orientations can be seen in the propensity to talk about Heritage landscapes instead of simply Heritage (Aitchison et Al., 2000, pp. 94-109).

Note 14. An approach that probably can be partly justified in the line of thought of certain archaeologists, according to whom "an archaeologist without landscape is already setting out with a reductive vision". For them the history of the landscape and archaeology are indissolubly linked (Goudineau \& Guilaine, 1991).

Note 15. For further details about the case of Gisacum, q.v. the paper of Aldo R. D. Accardi (Accardi, 2007, pp. 41-44).

Note 16. The competition announcement also stated explicitly that each of the équipes of project designers taking part should be composed of at least one heritage architect, a designer-architect and landscape architect. In December 1999, the team winning the competition to produce systems for the protection and presentation of the ruins of Gisacum was made up of Philippe Allart (heritage architect), the Agenzia Inca (designer-architects) and Epure (équipe of landscape architects), to whom were also added an economist, a professional figure in ever greater demand nowadays, given the consolidated attention directed towards merchandising and the effect of turning everything into a business, which affects every museum, whether indoor or outdoor.

Note 17. Caerleon is a small town near Newport (England), which has various interesting proposals for managing its own Roman pre-existences, among which we might mention the Roman Baths Museum connected to the balnea, and today partly protected by extensive roofing, the presentation of which was the idea of Peter Wardle (Strike, 1994, pp. 76 and 86).

Note 18 . When it was finally abandoned at the end of the $4^{\text {th }}$ cent. A.D,. the site was used as a "stone quarry" and every single reclaimable fragment was looted (Massy, 1997, pp. 29-56).

Note 19. This discovery owes everything to the French policy of show-casing, the precise regulations of which have the sole aim of protecting archaeological finds, and even consent the conservation of lucky finds (fouilles de sauvetage), as well as those already programmed or excavated. Control of archaeological potential as carried out by archéologie de prévention does not always result in an assured operation; luckily, however, in the case of "unforeseen" finds it is possible to avoid the impasse by applying the regulations for archéologie de sauvetage.

Note 20. The museum building was designed by the architects Philippe Chaix and Jean-Paul Morel, to meet the needs of research and conservation of the finds and presentation of the site. The project defined two buildings that are very different in their conception, but were planned so that the interior would open up on to the site, in perfect visual continuity. The first is firmly grounded and distinguished by an enormous flanking staircase and houses the museum's services (Robert, 1997, pp. 32-49).

Note 21. Scouring of the site, in fact, brought to light no fewer than sixty mosaic floors.

Note 22. Vienne, founded as a Celtic village on the left bank of the Rhone and established as a city by Julius Caesar in 47, B.C., extended over both banks of the Rhone; whereas the residential/commercial districts sprung up on the right bank, the political and religious centre and the buildings for spectacles were built on the left bank (Pelletier, 1982). 